\title{
Peertechz
}

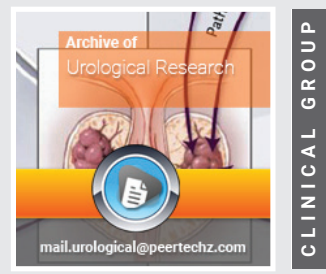

\section{Ethylene glycol monomethyl}

ether researchMy contribution Ph.D, Department of Biochemistry, College of Medicine, University of Ibadan, Nigeria,

E-mail: soluwatoyin81@yahoo.com/gmail.com

https://www.peertechz.com

Check for updates

\section{Oluwatoyin Adeyemo-Salami*}

Department of Biochemistry, College of Medicine, University of Ibadan, Nigeria

\section{Abstract}

Ethylene glycol monomethyl ether (EGME) is an industrial solvent that has wide application, including the aviation sector. It has been investigated scientifically to determine its effect on various body fluids and organs, especially the male reproductive organ. This is a review of research studies carried out using EGME with emphasis on the reproductive organs, and my investigations conducted with the solvent and in combination with a herb.

Since EGME is an industrial solvent, care should be taken when exposed to it and in the presence of herbal treatments.

\section{Abbreviations}

EGME: Ethylene Glycol Monomethyl Ether; MAA: Methoxy Acetic Acid; PP: Paullinia Pinnata

\section{Introduction}

Ethylene Glycol Monomethyl Ether (EGME) is enlisted among the group of solvents referred to as glycol ethers. Glycol ethers are alkyl ethers of ethylene glycol usually used in paints and this group is sub-divided into two classes: ethylene glycol ethers (EGEs) and propylene glycol ethers (PGEs). EGME belongs to the class of EGEs [1]. Synonyms for EGME are methyl oxitol, methyl cellosolve (commercially), methyl glycol, monomethyl ether, monomethyl glycol, monomethyl ethylene glycol ether or 2-methoxy ethanol [2].

The molecular formula is $\mathrm{C}_{3} \mathrm{H}_{8} \mathrm{O}_{2}$ and the molecular weight is $76.09 \mathrm{~g} / \mathrm{mol}^{2}$. The active biological oxidation product is Methoxy Acetic Acid (MAA). EGME is a reaction product of ethylene oxide and methanol. It is moderately volatile, highly inflammable, and colorless with very good solubility properties. As a result of the simultaneous hydrophilic and lipophilic properties, it has wide consumer and industrial applications. EGME finds use as an anti-freeze additive in hydraulic fluids and jet fuel. It is also used in stains, inks, paints and surface coating, photographic and photo lithographic processes, lacquers, production of food-contact plastics, textile and leather finishing, silk-screen printing, and in the semi-conductor industry $[3,4]$.

In humans and several other species, exposure to EGME either by ingestion, dermal absorption and/or inhalation has been reported to cause reproductive, hematopoietic and developmental toxicities with emphasis on testicular damage [5]. The evidences of haematological toxicities as a result of exposure to EGME include marrow depression and decrease in red blood cells count, platelet count, packed cell volume, haemoglobin concentration, mean corpuscular and mean corpuscular haemoglobin; pancytopenia and leucopenia $[6,7]$.

The evidences of reproductive toxicities as result of exposure to EGME or the active oxidation product, MAA, include decreased sperm production as a result of increased apoptosis of primary spermatocytes [8]; gene expression changes in germ cells and Leydig cells in-vitro [9]; hyper-secretion of progesterone from ovarian luteal cells both in-vivo and in-vitro; activation of caspases leading to apoptosis triggered by oxidative stress in spermatocytes [5]; prolonged estrus cycle, hypertrophy of corpora lutea evidenced by the presence of round to polygonal luteal cells with abundant vacuolated cytoplasm and ovulatory inhibition [10,11]; altered androgen-dependent processes in Leydig cells in-vitro [12]; affects microRNAs expression in the testes [13]; affects the antioxidant system and increase lipid peroxidation in the testes [14] and caused spermatocyte toxicity 
having correlation with decreased expression of spermatocytespecific genes [15].

Other acute and chronic toxic effects as a result of exposure to EGME have been reported in humans and animals [16] These include drowsiness; weakness; irritation of throat, eyes and nose; headache and decreased mental ability. Acute toxicity studies have shown that the $\mathrm{LD}_{50}$, (i.e. lethal dose, dose of $50 \%$ mortality) is $0.95 \mathrm{~g} / \mathrm{kg}$ body weight in guinea pigs, 0.89 to $1.425 \mathrm{~g} / \mathrm{kg}$ body weight in rabbits, 2.46 to $3.25 \mathrm{~g} / \mathrm{kg}$ body weight in male rats and $3.4 \mathrm{~g} / \mathrm{kg}$ body weight in female rats [17]. However, MAA toxicity can be mitigated by co-administration with D- glucose, serine, acetate, glycine, certain tricarboxylic acid pathway metabolites and formate [5].

This review is designed to briefly highlight research investigations carried out using EGME, with emphasis on the male reproductive organs, and to state my contribution to this.

\section{My contribution}

Our first study was aimed at investigating the effect of EGME on the antioxidant system of the reproductive organs of male rats by oral gavage. Fifty male Wistar rats were evenly distributed into five groups. Group I received distilled water, Groups II-V received EGME at 100, 200, 300 and $400 \mathrm{mg} / \mathrm{kg}$ body weight respectively. All administrations were done for fourteen days and the weight was monitored weekly. On day fifteen, the animals were sacrificed and reproductive organs were collected and weighed. The testes and epididymes were processed for the biochemical estimations, histopathology and spermatozoa analysis. Blood was collected by ocular puncture and was used for hematological analysis. The results showed that the percentage body weight gained weekly and the relative weight of the testes reduced significantly $(p<0.05)$ in the treatment groups. Hematological analysis reflected significant $(p<0.05)$ decreases in various parameters including hemoglobin concentration, white blood cell count, platelet count, neutrophils and red blood cell count, especially at the $400 \mathrm{mg} / \mathrm{kg}$ dose. The spermatozoa analysis showed decrease in testicular spermatozoa number, epididymal spermatozoa number, daily spermatozoa production, sperm motility and sperm viability in the treatment groups. Moreover, there was increased sperm abnormalities with an increased prevalence of curved- and bent- mid-pieces, and curved- and benttails, especially for the groups treated with 200 and $400 \mathrm{mg} /$ $\mathrm{kg}$ body weight dose of EGME. In the testes and epididymes, various antioxidant parameters such as catalase, glutathioneS-transferase, glutathione peroxidase, superoxide dismutase, lipid peroxidation and vitamin $\mathrm{C}$ were variably affected. The histopathology results complimented the findings with severe lesions being observed in the testes and epididymes at the 400 $\mathrm{mg} / \mathrm{kg}$ body weight dose. The study suggests that EGME exerts deleterious effects on the testes and epididymes by increasing the oxidative load in rats [18].

Our second study was conducted using co-administration of EGME with Paullinia pinnata methanol leaf extract. Paullinia pinnata (PP) is a medicinal plant whose parts are used for medicinal purposes traditionally in the treatment of various diseases including malaria, diarrhea and to help infertility which is currently a scourge globally. In this study, EGME was the infertility model. Sixty adult male Wistar rats were weightmatched into six groups of ten animals each. All administrations were done orally daily for twenty-one consecutive days as follows: Group I(control) - distilled water; Group II - $1.5 \mathrm{ml} /$ $\mathrm{kg}$ body weight of $10 \%$ dimethyl sulfoxide (vehicle); Group IIIEGME only (200 mg/kg); Group IV- PP only (200 mg/kg); Group $\mathrm{V}-\mathrm{EGME}+\mathrm{PP}$ at $100 \mathrm{mg} / \mathrm{kg}$ body weight and Group VI- EGME+PP at $200 \mathrm{mg} / \mathrm{kg}$ body weight. On day 22 , blood was collected for the analysis of the reproductive hormones. The animals were euthanized, dissected in order to excise the testes, epididymes, seminal vesicles, prostate gland and brain, and weighed. The brain, testes and epididymes were processed and used for spermatozoa analysis, antioxidant and anti-inflammatory assays, and histological examination appropriately. The plasma concentrations of the reproductive hormones including luteinizing hormone and follicle stimulating hormone were significantly increased in the co-administered groups while the plasma testosterone concentration was decreased. Similarly, the spermatozoa parameters were affected. The testicular spermatozoa number, spermatozoa motility and viability were reduced in the EGME only and co-administered groups. Antioxidant parameters including catalase and glutathione-Stransferase were affected in the epididymis, testes and brain in the EGME only and co-administered groups. The inflammatory markers; nitric oxide and myeloperoxidase, were also variably affected in the testes and epididymes of the EGME only and co-administered groups. The results were complemented by the histological observations in the testes, and hypothalamus. The conclusion was that $P$. pinnata leaves lack chemopreventive potential against ethylene glycol monomethyl ether- induced gonadotoxicity rather, it exacerbates the deleterious effects [19].

\section{Conclusion}

Taken together, the studies underscore the point that caution needs to be exercised in the exposure to EGME, especially in the light of co-exposure with herbal treatments.

\section{Acknowledgement}

The author appreciates Archive of Urological Research for recognition and invitation of this article.

\section{References}

1. Cordier S, Multigner L (2005) Occupational exposure to glycol ethers and ovarian function. Occup Environ Med 62: 507-508. Link: https://bit.ly/3hoMq59

2. PubChem 2019. 2-Methoxyethanol (compound). Link: https://bit.ly/2ZthLgU

3. Johanson G (2000) Toxicity review of ethylene glycol monomethy ether and its acetate. Critical Reviews in Toxicology 30: 307-345. Link: https://bit.ly/3mnjXjV

4. Takei M, Ando Y, Saitoh W, Tanimoto T, Kiyosawa N, et al. (2010) Ethylene glycol monomethyl ether -induced toxicity is mediated through the inhibition of flavoprotein dehydrogenase enzyme family. Toxicol Sci 118: 643-652. Link: https://bit.ly/2Rj8dAt 
5. Bagchi G, Waxman DJ (2008) Toxicity of ethylene glycol monomethyl ether: impact on testicular gene expression. International Journal of Andrology (Oxford) 31: 269-274. Link: https://bit.ly/2FgFeem

6. Starek A, Miranowicz-Dzierzawska K, Starek-Sweichowicz B (2010) Interactive effect of combined exposure to ethylene glycol ethers and ethanol on haematological parameters in rats. Health 2: 1054 -1064. Link: https://bit.ly/2GVg59t

7. Bendjeddou $M$, Khelili K (2014) The toxic effects of the ethylene glycol monomethyl ether (EGME) in male rabbits. Annals of Biological Research 5 8-15. Link: https://bit.ly/3mesCVB

8. Li LH, Wine RN, Chapin RE (1996) 2-methoxy-acetic acid (MAA) -induced spermatocyte apoptosis in human and rat testes, an in-vitro comparison. $J$ Androl 17: 538-549. Link: https://bit.ly/35vmSkg

9. Bagchi G, Zhang Y, Waxman DJ (2010) Impact of methoxy acetic acid on mouse Leydig cell gene expression. Reproductive Biology and Endocrinology 8: 65. Link: https://bit.ly/3bVfVKv

10. Dodo T, Taketa $Y$, Sugiyama M, Inomata A, Sonoda J, et al. (2009) Collaborative work on evaluation of ovarian toxicity. II) two - or 4 - week repeated dose studies and fertility study of ethylene glycol monomethyl ether in female rats. The Journal of Toxicological Sciences 34: SP 121-128. Link: https://bit.ly/32INceD

11. Taketa Y, Inomata A, Hosokawa S, Sonoda J, Hayakawa K, et al. (2011) Histopathological characteristics of luteal hypertrophy induced by ethylene glycol monomethyl ether with a comparison to normal luteal morphology in rats. Toxicol Pathol 39: 372-380. Link: https://bit.ly/33qvFBm
12. Bagchi G, Zhang Y, Stanley KA, Waxman DJ (2011) Complex modulation of androgen responsive gene expression by methoxy acetic acid. Reprod Biol Endocrinol 9: 42. Link: https://bit.ly/3hplwbU

13. Fukushima T, Taki K, Ise R, Horii I, Yoshida T (2011) Micro RNAs expression in the Ethylene glycol monomethyl ether- induced testicular lesion. J Toxicol Sci 36: 601-611. Link: https://bit.ly/3irXCis

14. Malik T, Gupta GD (2013) Effects of ethylene glycol monomethyl ether on testicular antioxidant system in adult rats. Research and Reviews: A Journal of Toxicology 3: 1-6. Link: https://bit.ly/32nssmP

15. Matsuyama T, Yabe K, Kuwata C, Ito K, Ando Y, et al. (2018) Transcriptional profile of ethylene glycol monomethyl ether-induced testicular toxicity in rats. Drug Chem Toxicol 41: 105-112. Link: https://bit.ly/3bR3G1t

16. National Institute for Occupational Safety and Health (NIOSH). 2019. Ethanol, 2-methoxy. Link: https://bit.ly/3mdJR9B

17. National Institute for Occupational Safety and Health (NIOSH) (1991) Criteria for a recommended Standard U.S Dept. of Health and Human Services. Occupational Exposure to Ethylene glycol monomethyl ether and Ethylene glycol monoethyl ether and their Acetates.

18. Adeyemo-Salami OA, Farombi EO (2018) Sub-acute toxicity study of ethylene glycol monomethyl ether on the antioxidant defense system of the testes and epididymes of Wistar rats. Nigerian Journal of Physiological Sciences 33: 195200. Link: https://bit.ly/32nKh5p

19. Adeyemo-Salami OA, Farombi EO (2019) Exacerbative effect of Paullinia pinnata methanol leaves extract on ethylene glycol monomethyl ether-induced testicular dysfunction in male Wistar rats. Archives Applied Medicine 7: 47-56. Link: https://bit.ly/3kfe1qX

\section{Discover a bigger Impact and Visibility of your article publication with} Peertechz Publications

Highlights

* Signatory publisher of ORCID

* Signatory Publisher of DORA (San Francisco Declaration on Research Assessment)

* Articles archived in worlds' renowned service providers such as Portico, CNKI, AGRIS, TDNet, Base (Bielefeld University Library), CrossRef, Scilit, J-Gate etc.

* Journals indexed in ICMJE, SHERPA/ROMEO, Google Scholar etc.

* OAI-PMH (Open Archives Initiative Protocol for Metadata Harvesting)

* Dedicated Editorial Board for every journal

* Accurate and rapid peer-review process

* Increased citations of published articles through promotions

* Reduced timeline for article publication

Submit your articles and experience a new surge in publication services (https://www.peertechz.com/submission).

Peertechz journals wishes everlasting success in your every endeavours.

Copyright: ( 2020 Salami OA. This is an open-access article distributed under the terms of the Creative Commons Attribution License, which permits unrestricted use distribution, and reproduction in any medium, provided the original author and source are credited. 